Prof. dr. sc. Hrvoje Kačer, redoviti profesor u trajnom zvanju

Pravni fakultet Sveučilište u Splitu

Dr. sc. Blanka Kačer, docentica

Pravni fakultet Sveučilište u Splitu

\title{
KRIZNE TOČKE ZA NASTANAK ŠTETE U VIJEKU SPORTAŠA, POSEBNO S ASPEKTA ULOGE TRENERA KOJI (NE) RADI LEGE ARTIS ${ }^{\prime}$
}

\author{
UDK: $347.4: 796.071 .43$ \\ Primljeno: 20. 01. 2019. \\ Izvorni znanstveni rad
}

\begin{abstract}
Autori su u ovom tekstu obradili pravni okvir moguće odštetne odgovornosti trenera prema sportašu. Pošli su od dvije hipoteze - prva je moguća odgovornost sportaša zbog stručnih propusta trenera u trenažnom procesu, druga je da treneri u pravilu nisu svjesni gdje su granice njihove odgovornosti. Potpuno su sigurni da trenerima po obje hipoteze prijeti velika opasnost. Naime, točno je da velik broj trenera radi a da nisu ispunili propisane zakonske uvjete, a još je sigurnije da treneri nemaju ni minimum pravničkih znanja. Autori su sigurni (iako je samo iznimno moguće zaključivati bez posebnog znanstvenog istraživanja) da stvarno vrlo mali broj trenera udovoljava pravnom standardu „pažnja dobrog stručnjaka“ iz Zakona o obveznim odnosima i to čak i kada se radi o stručnjacima s najvišim akademskim i stručnim i titulama i dosezima, što znači da je kod mnogih stanje stvarno zabrinjavajuće. Ukoliko ne bude kvalitetne naobrazbe, sličica u kojoj trener podučava dijete, a okružuju ga (i čine rad nemogućim) policajac, državni odvjetnik, privatni odvjetnik, vještak, možda i još poneka osoba - vrlo brzo će se od daleke budućnosti pretvoriti u zabrinjavajući prikaz stvarnosti. S nevjericom se svojedobno gledalo na takva predviđanja u odnosu na liječnike, a pokazalo se da je vrlo skora stvarnost bila (i ostala, kazali bismo) daleko lošija.
\end{abstract}

Ključne riječi: šteta, sportaš, trener, odgovornost, solidarna odgovornost, pažnja dobrog stručnjaka

\section{UVOD}

Vremenski vijek sportaša možemo odrediti, odnosno ograničiti na način da početak u užem smislu predstavlja početak treniranja (u smislu bilo kakvog organizacijskog oblika treniranja, uključujući i onakav kakav provode tzv. samouki sportaši), a početak u širem smislu predstavlja onaj dio aktivnosti koji se odnosi na

1 Ambicija ovoga testa daleko je veća nego što to izgleda prima faciae. Naime, u izgledu je čitav niz tekstova različitih autora koji će u fokusu imati trenere i njihov posao s različitih aspekata. Već sada možemo najaviti za sljedeće savjetovanje koautorski tekst nastavnika s Pravnog fakulteta i Sveučilišnog odjela Zdravstveni studiji, s ključnom ulogom liječnika specijalista sportske medicine, posebno i člana Zdravstvene komisije Hrvatskog olimpijskog odbora doc. dr. sc. med. Dinka Pivalice. 
vrijeme upoznavanja s konkretnim sportom, neovisno o tome hoće li se konkretna osoba (dijete ili odrasli) i koliko baviti tim sportom. Kraj navedenog vremenskog tijeka može biti definiran kao nečija smrt (ako se do smrti bavio sportom) ili drugi trenutak za života nakon kojega se više nije bavio sportom, neovisno o razlogu.

Krizne točke (u svezi s ulogom trenera) nešto su što je (kao i bilo što drugo) podložno promjenama, ali unatoč tome, s dosta velikom sigurnošću možemo kao primjere (bez ikakvih pretenzija na bilo koji oblik taksativnosti) navesti faze u razvitku sportaša, pa tako:

a) odabir sporta - sportova za koje je netko najnadareniji i eventualno discipline unutar određenog sporta (npr. je li netko uključen u atletiku kao atletičar u smislu osobe koja vježba trčanje na srednjim prugama ili pak bacanje kugle ili skok s motkom);

b) odabir ruke i noge, odnosno utvrđenje radi li se o dešnjaku (dešnjakinji) ili ljevaku (ljevakinji);

c) planiranje treninga;

d) vježbe tehnike posebno prilagođene određenom sportu, odnosno disciplini unutar sporta;

e) vježbe kondicije;

f) vježbe snage;

g) vježbe disanja;

h) prehrana;

i) prijelaz na intenzivni trening;

j) elementi taktike i strategije;

k) promjena podloge na kojoj se trenira i nastupa;

1) planiranje nastupa;

m) učenje što je doping i kako ga izbjeći i nadomjestiti nečim dopuštenim;

n) 
Svaki od navedenih elemenata može se izraditi i provoditi na različitim razinama, od one početne, pa sve do one napredne. Bitno je da je svaki trener kompetentan u svakoj od faza djelovati i to barem na početnoj razini. Svi smo svjesni da najbolje rezultate daje samo i isključivo timski rad prema znanstveno utemeljenom programu, ali sve je to jako ograničeno cijenom koštanja, ali ne i samo klasičnom cijenom koštanja. Naime, brojne specijalnosti su insuficijentne već i po broju raspoloživih stručnjaka, a kada (kojim slučajem, to nije baš često niti je pravilo) broj stručnjaka zadovoljava, u pravilu će raspored na širem podruju biti potpuno neprikladan (npr. na hrvatskom primjeru to je notorna koncentracija na glavni grad Zagreb). Sukladno načelu realiteta, treba prihvatiti da je (ili bi barem tako u idealnom scenariju trebalo biti) na najvećim stručnjacima odgovornost izrade makroplanova i rad s najboljima, a najveći dio sportaša najbolje će trenere vidjeti samo „na slici“ i tu se ne može ništa promijeniti.

Ovaj tekst temelji se na polaznoj hipotezi da su treneri (generalno, neovisno o stanju kod svakog pojedinog trenera) u obavljanju svojeg posla izloženi gotovo nevjerojatnim zahtjevima koji prepoznaju trenera isključivo kao nadčovjeka, ${ }^{2}$ a tim zahtjevima ne mogu odgovoriti ni oni rijetki i najbolji, kamo li oni ostali, uključujući i one (netko i to mora biti) najlošije. Pri tome ne mislimo samo na stručna znanja u užem smislu (npr. u tenisu kako izvesti pojedini udarac) nego i na daleko šira znanja, od onih na području tehnike i taktike, preko snage i kondicije, pa sve do znanja iz područja borbe protiv dopinga i barem minimalnih pravničkih znanja. Istraživanje i zaključci u tekstu potvrdit će ili demantirati tu hipotezu (kao i onu drugu koja slijedi u nastavku), te po potrebi predložiti promjene - poboljšice de lege ferenda, na boljitak trenera, ali i sporta i sportaša radi kojih u konačnici treneri i postoje.

Druga (polazna) hipoteza jest to da treneri u pravilu nisu svjesni gdje su granice njihove odgovornosti i o kojim se to sve vrstama odgovornosti (građanskopravna, kaznenopravna, prekršajnopravna, stegovna) uopće radi. Iako smo u ovom tekstu koncentrirani na građanskopravnu odgovornost, notorno je da postoje mnoge druge i da im je apsolutni minimum u saznanju za te odgovornosti i elementarnom znanju kako te odgovornosti izbjeći.

\section{DEFINICIJE NEKIH POJMOVA, POSEBNO I TRENAŽNOG PROCESA}

Činjenica je da je obavljanje (i to ne bilo kako, nego u skladu sa standardom lege artis) trenažnog procesa nešto što nije definirano pravnim normama sportskog prava, ili barem nije izravno definirano tim normama. To znači da je moguće da, bez bilo kakve formalne promjene pravne norme, dođe do promjene njezina sadržaja tako što je isti promijenjen unutar sporta. Tako se, ne tako davno, sve dramatično

\footnotetext{
${ }^{2}$ U literaturi je poznat njemački izraz Übermensch (prema filozofiji Friedricha Nietzschea).
} 
promijenilo pojavom Fosbury flopa ${ }^{3} \mathrm{u}$ atletici (skok u vis), pojavom Björna Borga i njegova dvoručnog backhanda, ${ }^{4}$ a da pojava nije ništa posebno baš za sport, pokazuje činjenica da niti jedna pravna norma (pa ni ona medicinska) ne sadrži podatak o tome kako se utvrđuje smrt čovjeka, nego se ta definicija mijenja sukladno razvitku medicine kojoj je pravo prešutno to prepustilo - nekad je to bilo srce, danas je rad mozga, sutra će biti možda nešto treće).

Premajednoj definiciji, ,trenažni proces je složena aktivnost upravljanja sportskim razvitkom. Ovaj proces kreće od selekcije i identifikacije talenta, a završava krajem karijere sportaša. Trening je obično sinonim za trenažnu epizodu, odnosno relativno kratki vremenski okvir u kojem sportaš izravno utječe na povećanje svojih radnih sposobnosti. Unutarnji alati samog treninga jesu opseg, intenzitet i pauza“.5

Kao što se često događa, i kod trenažnog je procesa ključni problem prava mjera. To znači da je loše rješenje premali intenzitet, ali često je još i daleko veći problem pretreniranost. Do pretreniranosti dolazi uslijed (pre)velikih i (pre)naglih trenažnih opterećenja koja treneri često daju sportašima bez razmišljanja (ali i bez znanja koja bi ta razmišljanja učinila učinkovitima i odluke razumnima) o njihovu funkcionalnom statusu. Upravo takvo upravljanje opterećenjima uzrokuje, pored ostaloga, nedostatak prilagodbe i neoporavljanje od treninga. U kompletnom lancu nastanka umora većina teoretičara zamora smatra da je nervno-mišićni sustav taj koji prvi strada, te da zamor istog prouzrokuje pad cijeloga sustava.

Krizna točka nakon nastavka treninga nakon dulje pauze posebno je osjetljiva. Potrebno je trenirati gotovo kao početnik; i volumen i intenzitet treninga trebaju biti znatno manji od onih uobičajenih. Takav je pristup potreban kako bi se vezivna tkiva, mišići i živčani sustav ponovno adaptirali na trenažne podražaje. Intenzitet bi trebao biti između 60-70 posto onoga s kojim si prije radio i poželjno je barem prvih nekoliko tjedana trenirati cijelo tijelo. Iako se sportašu nakon pauze čini da je pun snage i da bi mišići mogli podnijeti veća opterećenja, vezivna tkiva (tetive i ligamenti) još nisu spremna i zato na njih treba paziti. Možda se čini demotivirajućim krenuti ispočetka, ali tijelo pamti zahvaljujući tzv. memoriji mišića. Mišićna

Richard Douglas Fosbury (rođen 6. ožujka 1947.) američki je skakač u vis, osvojio je zlatnu medalju na Olimpijskim igrama 1968. god. s revolucionarnom, potpuno novom tehnikom skoka, tehnikom nakon koje više nikad nije bilo i neće biti isto jer sada $100 \%$ skakača rabi tu tehniku.

4 Björn Borg svakako je jedan od najvećih tenisača svih vremena. Rođen je 6. lipnja 1956. i proglašen najboljim švedskim sportašem svih vremena. Poznatiji je vjerojatno po uvođenju dvoručnog backhanda nego po svojih 11 titula osvojenih na samo dva turnira grand slam (Wimbledon i Roland Garros) u razdoblju 1974. - 1981., uz još čak pet uzastopnih finalnih nastupa (bez pobjede) na US Openu (tada je to bio Forest Hills) 1976. - 1980. Pored neobjašnjive činjenice da na preostalom turniru grand slam (Australian Open) nikada nije otišao dalje od trećeg kola, činjenica je da je prekinuo karijeru (svojevoljno, nije bila bolest, ozljeda ili nešto slično) zaključno s 1981. god., dakle s nepunih 26 godina, što otvara dvojbu što bi bilo da je nastupao ne kao Roger Federer, nego kao tenisač s prosječnim trajanjem karijere. U 1982. i 1983. god. odigrao je samo po jedan turnir (Monte Carlo), što se u 1984. god. ponovilo u Stuttgartu. S tog aspekta, njegovih 11 grand slam titula djeluje kao (relativno) mnogo više od Rogera Federera koji s 38 godina nastupa još uvijek i u 2018. je godini osvojio svoj 20. grand slam naslov (pobjeda protiv Marina Č́ilića $6: 2,6: 7(5), 6: 3,3: 6,6: 1)$.

5 Nedim Čović, „Osnove periodizacije, kreiranja i planiranja vođenja procesa treninga“, objavljeno na www.atleta.ba, uvid obavljen 24. I. 2019., 14:21h. 
memorija pamti motoriku pokreta, pa čak i razvoj mišića - ako su oni jednom bili veći i snažniji, jezgra stanice mišića to „pamti”. Zahvaljujući toj fiziološkoj i neurološkoj sposobnosti mišićnog pamćenja, vraćanje u formu nakon duge pauze bit će puno brže nego u vrijeme kada je sportaš tek ulazio u svijet treninga. ${ }^{6}$

Pojam ili naziv kineziologija nastao je od riječi „,kinezis“ (pokret, kretanje) i „logos“ (znanost), što stvarno znači da je to znanost o kretanju. Međutim, danas se odmaklo daleko od ovih početaka i kineziologiju definiramo kao znanost koja proučava zakonitosti upravljanja procesom vježbanja i posljedice djelovanja tih procesa na ljudski organizam, što svakako unapređuje zdravlje. Kineziologija i sport svakako nisu sinonimi, ali dijele mnogo toga, pa tako i podjelu na rekreacijski i natjecateljski dio.

Iako bi bilo za očekivati da je svima jasno koja je razlika između zagrijavanja i istezanja (pored ostaloga i kada što od toga slijedi), te razgibavanja, to ipak nije baš tako i nekima čak ni ti pojmovi nisu potpuno jasni. Zagrijavanje je proces koji slijedi kako prije nastupa tako i prije treninga u užem smislu (u tenisu npr. to je prije uzimanja reketa u ruku i početka prebacivanja loptice preko mreže) i služi kao uvod u ne samo veći napor, nego i u naglije pokrete tijekom treninga. Istezanje slijedi nakon treninga i služi tomu da zbog prenaglog prijelaza iz punog treninga $u$ mirovanje ne dođe do neželjenih posljedica.

Igra je stariji i širi pojam od sporta (ako igru shvatimo najšire moguće - kao igru života). Igra je tipičan primjer spekulacije u realnosti, a osnovni pojam igre je nadograđivan, pa danas poznajemo elementarne igre, sportske igre, narodne igre, dječje igre. ${ }^{7}$

\section{PRAVNI IZVORI - PRAVNA VRELAs I PRAVILA TUMAČENJA}

Kao i glede bilo kojeg drugog pravnog pitanja, temeljni pravni izvor svakako je Ustav Republike Hrvatske, ${ }^{9}$ neovisno o tome što Ustav u pravilu zahtijeva provedbene odredbe nižeg pravnog ranga (u pravilu se radi o zakonima).

S obzirom na to da se radi o području građanskopravne odgovornosti (makar i unutar sportskog prava koje se formira u posebnu pravnu granu), temeljni pravni izvor nakon Ustava jest, iako nije (barem ne onaj klasični) sportski zakon, Zakon o

\footnotetext{
6 Vidjeti tako u: Marko Lončar, „Povratak u trenažni proces poslije bolesti“, www.building-body. com - uvid obavljen 24. I. 2019., 08:00h.

7 Zoran Mašić, Teorija sporta, Fakultet za menadžment u sportu, Beograd, 2006., str. 33.

8 Vidjeti više u: Jozo Čizmić, Blanka Kačer, „Pravni izvori sportskog (materijalnog i postupovnog) prava“, u: Hrvoje Kačer et alt., Sportsko pravo, Pravni fakultet Sveučilišta u Splitu, Split, 2018., str. 23-37.

9 Ustav Republike Hrvatske (NN 56/90, 135/97, 8/98 - pročišćeni tekst, 113/00, 124/00 - pročišćeni tekst, 28/01., 41/01 - pročišćeni tekst, 55/01, 76/10 - promjena Ustava, 85/10, 5/14 - nastavno: Ustav).
} 
Dr. sc. Hrvoje Kačer i dr. sc. Blanka Kačer: Krizne točke za nastanak štete u vijeku sportaša, posebno... Zbornik radova Pravnog fakulteta u Splitu, god. 56, 2/2019, str. 285.- 304.

obveznim odnosima ${ }^{10}$ koji je sedes materiae glede te vrste odgovornosti. Posebno (iako je prošlo već više od 12 godina, ${ }^{11}$ ipak još uvijek ima odštetnih slučajeva koji su u tijeku u svezi sa štetama nastalima do 31. prosinca 2005. god.) treba voditi računa da se ZOO odnosi samo na one obveznopravne odnose nastale od 1. siječnja 2006. god., a ne i na one prije, na koje se odnosi i primjenjuje propis istog naziva, inače preuzet iz bivše države. ${ }^{12}$

Kako bi se odredbe o odštetnoj odgovornosti uopće mogle primijeniti i kako bi se moglo utvrditi je li netko postupao ili nije postupao lege artis (posljedično i ima li krivnje ako se radi o toj vrsti odgovornosti), pravni izvori su i svi tzv. sportski (ili sportski u užem smislu, naime na svoj način je i Zakon o obveznim odnosima sportski propis, barem u širem smislu) propisi, pa tako u prvom redu Zakon o športu. ${ }^{13}$

Budući da će se naknada štete u pravilu rješavati u parničnom postupku, to značenje pravnog izvora ima i Zakon o parničnom postupku. ${ }^{14}$

S obzirom na činjenicu što se ovaj tekst bavi štetama u sportu, pravni izvor predstavlja čitav niz bilo zakonskih (mnoge će prima facie možda iznenaditi da je - kako je izuzetno bitno odrediti tko je vlasnik nekog športskog igrališta - pravni izvor i Zakon o vlasništvu i drugim stvarnim pravima), ${ }^{15}$ bilo podzakonskih akata

10 Zakon o obveznim odnosima (NN 35/05, 41/08, 125/11, 78/15, 29/18 - nastavno: ZOO ili Zakon o obveznim odnosima).

11 Od 1. I. 2006. kao dana stupanja na snagu Zakona o obveznim odnosima.

12 Zakon o obveznim odnosima (NN 53/91, 73/91, 111/93, 3/94, 7/96, 91/96, 112/99, 88/01 nastavno: RZOO ili Raniji Zakon o obveznim odnosima).

13 Zakon o športu $(71 / 06,150 / 08,124 / 10,124 / 11,86 / 12,94 / 13,85 / 15,19 / 16$ - nastavno: ZOS ili Zakon o sportu ili Zakon).

14 Zakon o parničnom postupku (NN 148/11 - Pročišćeni tekst Zakona o parničnom postupku obuhvaća Zakon o parničnom postupku, objavljen u SL SFRJ, br. 4/77 i 36/77 (ispr.) te njegove izmjene i dopune objavljene u SL SFRJ, br. 6/80, 36/80, 43/82, 69/82, 58/84, 74/87, 57/89, 20/90, $27 / 90$ i 35/91, Zakon o preuzimanju Zakona o parničnom postupku, objavljen u NN, br. 53/91 (stupio na snagu 8 . listopada 1991.), Zakon o izmjenama Zakona o parničnom postupku, objavljen u NN, br. $91 / 92$ (stupio na snagu 8. siječnja 1993.), Zakon o izmjenama i dopunama Zakona o parničnom postupku, objavljen u NN, br. 112/99 (stupio na snagu 6. studenoga 1999.), članak 50. Zakona o arbitraži, objavljen u NN, br. 88/01 (stupio na snagu 19. listopada 2001.), Zakon o izmjenama i dopunama Zakona o parničnom postupku, objavljen NN, br. 117/03. (stupio na snagu 1. prosinca 2003.), članak 129. Zakona o izmjenama i dopunama Ovršnog zakona, objavljen u NN, br. 88/05. (stupio na snagu 28. srpnja 2005.), Odluku USRH, br. U-I-1569/04. i dr., objavljena u NN, br. 2/07 i 96/08, Zakon o izmjenama i dopunama Zakona o parničnom postupku, objavljen u NN, br. 84/08. (stupio na snagu 1. listopada 2008., osim odredbe čl. 49. koja stupa na snagu na dan prijama Republike Hrvatske u Europsku uniju), ispravak Zakona o izmjenama i dopunama Zakona o parničnom postupku, objavljen u NN, br. 123/08.) te Zakon o izmjenama i dopunama Zakona o parničnom postupku, objavljen u NN, br. 57/11. (stupio na snagu 2. lipnja 2011., osim odredbi čl. 14., čl. 29. u dijelu koji se odnosi na Europski sud i čl. 49. koje stupaju na snagu na dan prijama Republike Hrvatske u Europsku uniju), NN 25/13 - nastavno: ZPP ili Zakon o parničnom postupku).

15 Zakon o vlasništvu i drugim stvarnim pravima (NN 81/15) - pročišćeni tekst. Pročišćeni tekst Zakona o vlasništvu i drugim stvarnim pravima obuhvaća Zakon o vlasništvu i drugim stvarnim pravima (NN 91/96), Zakon o izmjenama i dopunama Zakona o prodaji stanova na kojima postoji stanarsko pravo (NN 68/98), Odluku Ustavnog suda Republike Hrvatske br. U-I-58/97, U-I-235/97,U-I-237/97, U-I1053/97 i U-I-1054/97 od 17. studenoga 1999. (NN 137/99), Odluku Ustavnog suda Republike Hrvatske br. U-I-1094/99 od 9. veljače 2000. (NN 22/00), Zakon o dopuni Zakona o vlasništvu i drugim stvarnim pravima (NN 37/00), Zakon o izmjeni i dopuni Zakona o vlasništvu i drugim stvarnim pravima (NN 114/01), Zakon o izmjenama i dopunama Zakona o vlasništvu i drugim stvarnim pravima (NN 141/06), 
iz korpusa sportskog prava (kako u užem smislu, kao što je Zakon o sportu, tako i u širem smislu, kao što je Zakon o obveznim odnosima). Pri tome, nažalost, moramo naglasiti jednu gotovo nevjerojatnu stvar, jedan gotovo nevjerojatan podatak iz kojega je ne samo mogla, nego po našem mišljenju i morala proizići nečija odgovornost, a (barem koliko je javno poznato) do toga ipak nije došlo. Naime, ZOS je propisao obvezno donošenje niza podzakonskih akata u relativno kratkom razdoblju posebno propisanom za svaki od tih podzakonskih akata. Nije toliko bitno (s obzirom na kontekst i da ima i lošijih stvari od kašnjenja) što je svaki, baš svaki od donesenih podzakonskih akata donesen s velikim zakašnjenjem, ${ }^{16}$ bitno je da ni danas, gotovo 13 godina od donošenja ZOS-a, ${ }^{17}$ niz tih akata nije donesen, a kako je za 2019. god. najavljen ${ }^{18}$ potpuno novi Zakon o sportu, očito je da do promjene glede tih podzakonskih akata neće ni doći. Posebno pravno značenje imaju međunarodni ugovori koji temeljem Ustava imaju nadzakonsku snagu, pod uvjetom ratificiranja i objave.

Značenje pravnog izvora ima i svaki drugi propis (kako zakonske, tako i podzakonske razine) koji se, bilo izravno bilo neizravno, bavi pitanjima sporta i odštetne odgovornosti.

Ono što je vrlo značajno naglasiti jest i uloga znanosti ${ }^{19}$ (koja djeluje SAMO I ISKLJUČIVO snagom argumenta) ${ }^{20}$ kao (makar i neformalnog) izvora prava sui generis, poglavito u slučaju pitanja kao što je tumačenje u pravu, a koje je neka vrsta pravne stečevine uopće, dakle (uvjetno rečeno) iznad svake konkretne pravne norme, na neki način i iznad ograničenja koja predstavljaju granice država i regija. Poznato je da mnogi postupak tumačenja nedopustivo pojednostavljuju, kao da je to postupak koji može obaviti svaki čovjek zdravog razuma, pa bio on i bez ikakva pravnog znanja, što ni u kojem slučaju nije točno jer je to obična i vrlo opasna

Zakon o izmjenama i dopunama Zakona o vlasništvu i drugim stvarnim pravima (NN 146/08), Zakon o izmjenama Zakona o vlasništvu i drugim stvarnim pravima (NN 38/09), Zakon o izmjeni i dopuni Zakona o vlasništvu i drugim stvarnim pravima (NN 153/09), Zakon o izmjeni Zakona o vlasništvu i drugim stvarnim pravima (NN 143/12) i Zakon o izmjeni Zakona o vlasništvu i drugim stvarnim pravima (NN 152/14), u kojima je utvrđeno vrijeme njihova stupanja na snagu., (NN 94/2017. - nastavno: ZV ili Zakon o vlasništvu).

16 Vidjeti tako i više u: Hrvoje Kačer, „Uvod i osobe u športu“, u: Ivica Crnić, Jadranko Crnić, Igor Gliha et alt., (Uvod u) športsko pravo, Inženjerski biro d.d., Zagreb, 2009. str. 7-11.

17 Zakon o športu Hrvatski je sabor donio na sjednici 9. lipnja 2006. godine.

18 Istina, ta najava postojala je i za prethodne dvije godine.

19 Namjerno se nismo ograničili na pravnu znanost, kako se to uobičajeno radi. Naime, baš na području odgovornosti za štetu i uopće štete jasna je povezanost i međuovisnost pravne i medicinske znanosti (npr. baš medicina daje odgovor na pitanje je li netko i u kojem trenutku umro, o kakvim se bolovima npr. radi i dr.). Naravno, nema ograničenja samo na područje medicine i prava, radi se o znanosti uopće, a pojedini njezini dijelovi (pravna znanost uvijek) za pravne su probleme više bitni.

20 Drukčije je kada je neki znanstvenik istodobno (što i nije baš rijetkost) u položaju suca ili čak i predsjednika nekog suda, ili dužnosnika (posebno ako je ministar i sl.) u kojem slučaju iza njegovih ili njezinih stavova stoji i položaj koji u tom trenutku obnaša jer je teško vjerovati da će u nekom tekstu ili izlaganju braniti jedan, a u vijećanju npr. drugi stav (primjera ima mnogo, od baš svih predsjednika Ustavnog suda Republike Hrvatske od osamostaljenja Republike Hrvatske do danas, preko aktualnog i prethodnog i pretprethodnog predsjednika Vrhovnog suda Republike Hrvatske, do većeg broja sudaca Ustavnog suda Republike Hrvatske u aktualnom i prethodnom sazivu, niza zastupnika u Hrvatskom saboru...). 
zabluda koja može odgovarati samo onima kojima nije ni do pravne sigurnosti ni do vladavine prava kao temelja svake pravne države. Naime, naravno da svaka pismena osoba može pročitati svaki napisani tekst, ali između čitanja i tumačenja ogromna je razlika.

Svaka pravna norma predstavlja skup riječi koje imaju određeno značenje ili određena značenja koja treba utvrditi. Uslijed niza uzroka (pri čemu bogatstvo nekog jezika, kao i gramatika, imaju značajnu ulogu), tom sklopu riječi često je dosta složeno dati pravo značenje ${ }^{21}$ i na tom se zadatku vidi vrsnoća onoga tko primjenjuje (tumači) pravnu normu. Postoje općeprihvaćena pravila tumačenja, u dosta velikoj mjeri je prihvaćen i njihov međusobni odnos, ali ipak u praksi (pre)često dolazi do problema. Ciljna (teleološka) metoda tumačenja jest metoda kojom se ispituje uloga pravne norme $u$ društvu i zaključuje da je njeno pravo značenje u određenom pravnom odnosu ono značenje koje najbolje izražava vladajuće društvene ciljeve. Upravo ciljna metoda se (kako smo već naglasili) smatra odlučnom u svim onim slučajevima postojanja više mogućih (vjerojatnih) pravih značenja, pa njena uporaba mora otkriti ono (jedino) pravo značenje te pravne norme. Zbog toga je ciljno tumačenje najvažnije, odlučno i završno u postupku tumačenja (razumijevanja) pravnih normi, a sva druga pravila tumačenja njemu su podređena i njemu služe. ${ }^{22}$

Potrebito je naglasiti i ulogu (sudske) prakse kao izvora prava sui generis. Pri tome treba naglasiti da sudska praksa (za razliku od znanosti) djeluje snagom argumenta (što vrijedi i za znanost), ali i argumentom snage, s obzirom na to da viši sudovi imaju ovlast nametnuti svoje pravne stavove nižima. Uvažavajući apsolutno sve sudove i tvrdeći odgovorno da je stanje hrvatskog pravosuđa danas bitno bolje nego bilo kada od osnutka hrvatske države (što još uvijek ne znači i to da je stanje dobro), potrebno je naročito istaknuti položaj i ulogu Ustavnog suda Republike Hrvatske. To je sud koji je, što temeljem svoje uloge koja mu je dana pozitivnim propisima a što via facti, došao u položaj da apsolutno kontrolira sudsku praksu i da preuzme ulogu koju je Ustav namijenio Vrhovnom sudu Republike Hrvatske u čl. 118. st. 1. koji glasi:

Vrhovni sud Republike Hrvatske, kao najviši sud, osigurava jedinstvenu primjenu zakona i ravnopravnost građana.

Potpuno je jasno, podržavali mi to ili s najvećom žestinom kritizirali, da Vrhovni sud Republike Hrvatske nema baš nikakve mogućnosti ispuniti svoju ulogu iz navedenog članka Ustava. Dijelom je tome pridonio zakonodavac ovako čudnom normativom.

Konačno, zato što je Republika Hrvatska članica Europske unije, iznimno veliku ulogu imaju različiti akti koji čine ono što se obično naziva europska pravna stečevina ili acquis communautaire.

21 Školski je primjer igra riječi „Ići ćeš vratiti se nećeš poginuti”.

22 Vidjeti tako u: Nikola Visković, Teorija države i prava, Birotehnika, Zagreb, 2001., str. 250., više o tome i u: Oleg Mandić, Sistem i interpretacija prava, Narodne novine, Zagreb, 1971., str. 201 i dalje. 
Unutar sudske prakse kao izvora prava sui generis treba posebno istaknuti i Europski sud za ljudska prava ${ }^{23}$ čije odluke dosljedno provode hrvatski sudovi, uključujući i Ustavni sud Republike Hrvatske. Primjera za uvođenje tim putem koji zaobilazi hrvatskog zakonodavca ima velik broj, s očitim trendom povećanja, a ne smanjenja.

\section{O ŠTETI OPĆENITO24}

\section{1. DEFINICIJA ŠTETE}

Prema članku 1046. ZOO-a, koji sadrži zakonsku definiciju štete, šteta je umanjenje nečije imovine (obična šteta), sprečavanje njezina povećanja (izmakla korist) i povreda prava osobnosti (neimovinska šteta).

\section{2. SUBJEKTI OBVEZNOG ODNOSA ODGOVORNOSTI ZA ŠTETU}

Subjekti obveznog odnosa odgovornosti za štetu jesu odgovorna osoba za štetu i onaj tko je pretrpio štetu - oštećenik. To mogu biti naravne ili fizičke ${ }^{25} \mathrm{i}$ pravne osobe (članak 16. ZOO-a). Za štetu odgovara osoba koja je prouzročila štetu (štetnik). Od ovog općeg pravila ZOO predviđa izuzetke u kojima osoba koja je prouzročila štetu (štetnik) ne odgovara za štetu koju je prouzročila, već za štetu odgovara osoba na koju ZOO upućuje, a koju možemo nazvati i štetnikom u širem smislu. ${ }^{26}$ Tako su kod naravnih ili fizičkih osoba u ZOO-u pretpostavke odgovornosti posebno određene s obzirom na njihovu ubrojivost (sposobnost za rasuđivanje - članak 1050., članak 1055.) i poslovnu sposobnost (članak 1051., članak 1056. - 1060.). Pravnoj osobi priznaje se pravna (članak 17.) i poslovna (članak 18.) sposobnost. Pravna osoba je, dakle, deliktno sposobna i odgovara za štetu koju njezino tijelo prouzroči trećoj osobi u obavljanju ili u vezi s obavljanjem svojih funkcija (članak

23 Europski sud za ljudska prava čije je sjedište Strasbourg u Francuskoj (engl. European Court of Human Rights Strasbourg, franc. Cour européenne des droits de l'homme Strasbourg).

24 Ovaj dio je u bitnom preuzet iz: Hrvoje Kačer, „Odgovornost za povrede u športu-medicinskopravni aspekt", u: Aktualnosti zdravstvenog zakonodavstva i pravne prakse, Zbornik radova sa savjetovanja održanog u Novalji 6. i 7. svibnja 2011. god., str. 165-183.

25 Nažalost, unatoč jednoglasnom prijedlogu radne skupine za ZOO (pod vodstvom zasigurno vodećeg hrvatskog autoriteta za medicinsko pravo, $u$ to vrijeme predsjednika Ustavnog suda Republike Hrvatske, profesora Petra Klarića), nije prihvaćen prijedlog da se pojam fizička osoba (po uzoru na mnoga strana rješenja) zamijeni pojmom naravna osoba, ili da se barem oba pojma kao alternative unesu u zakonski tekst.

${ }^{26}$ U tom bi slučaju onaj uobičajeni štetnik bio štetnik u užem smislu toga pojma. 
Dr. sc. Hrvoje Kačer i dr. sc. Blanka Kačer: Krizne točke za nastanak štete u vijeku sportaša, posebno... Zbornik radova Pravnog fakulteta u Splitu, god. 56, 2/2019, str. 285.- 304.

1062.). Za štetu koju zaposlenik u radu ili u svezi s radom prouzroči trećoj osobi odgovara poslodavac u uvjetima odredbe članka 1061. ZOO-a (osim ako dokaže da su postojali razlozi koji isključuju odgovornost zaposlenika). Oštećenik je svaka fizička ili naravna i pravna osoba koja trpi štetu. ${ }^{27}$

\section{3. ZAKONSKE PRETPOSTAVKE ODGOVORNOSTI ZA ŠTETU}

Odgovornost za štetu jest obveznopravni odnos u kojem je jedna strana dužna drugoj strani popraviti štetu, a druga je od prve ovlaštena zahtijevati taj popravak. ${ }^{28}$ Odgovornost za štetu nastaje pod pretpostavkom da je osoba odgovorna za štetu (štetnik) počinila protupravnu štetnu radnju zbog koje je nastala šteta osobi koja traži popravak štete (oštećenik) i ako postoji uzročna veza između štetne radnje i štete kao posljedice. Sve navedene pretpostavke moraju biti ispunjene kumulativno. Tako su pretpostavke odgovornosti za štetu (pored subjekata):

1/ štetna radnja štetnika, 2/ šteta, 3/ uzročna veza između štetne radnje i štete (kauzalni neksus) i 4/ protupravnost. ${ }^{29}$

Štetna je radnja svaka radnja, činidba (commissio) ili propust (omissio) štetnika kojom se oštećeniku nanosi šteta. Javlja se kao građanski delikt i povreda ugovornog odnosa. Kod građanskog delikta (deliktna odgovornost) između stranaka prethodno ne postoji ugovorni odnos. Prema odredbi članka 8. ZOO-a svatko je dužan uzdržati se od postupka kojim se može drugome prouzročiti šteta (neminem laedere). Utoliko svako postupanje (činidba ili propust) kojim se drugome prouzrokuje šteta, a koje postupanje nije povreda ranije preuzete ugovorne obveze, predstavlja odnosno može predstavljati građanski delikt. Između štetnika i oštećenog, u ovom slučaju, nastaje izvorna i samostalna obveza odgovornosti za štetu. O povredi ugovornog odnosa (ugovorna odgovornost) govorimo u okolnostima kada stranka svojim postupanjem (činidba ili propust) vrijeđa (ne poštuje) postojeću ugovornu obvezu. Sukladno odredbi članka 9. ZOO-a, sudionici u obveznom odnosu dužni su ispuniti svoju obvezu i odgovorni su za njezino ispunjenje, pa kada dužnik ne ispuni svoju obvezu ili zakasni s njenim ispunjenjem, vjerovnik je ovlašten zahtijevati i popravljanje štete koju je zbog tog pretrpio (članak 342. ZOO-a). Sukladno odredbi članka 6. ZOO-a, zabranjeno je ostvarivanje prava iz obveznog odnosa suprotno svrsi zbog koje je ono propisom ustanovljeno ili priznato. Utoliko obveznopravni odnos može povrijediti i vjerovnik obveznopravnog odnosa. U literaturi ${ }^{30}$ se kao specifičan oblik izvanugovorne odgovornosti navodi i predugovorna odgovornost (strana koja je pregovarala ili prekinula pregovore suprotno načelu savjesnosti i poštenja - članak

27 Vidjeti u: Hrvoje Kačer, Ante Perkušić, u: Vilim Gorenc i dr., Komentar Zakona o obveznim odnosima, RRIF, Zagreb, listopad 2005., str. 1606.

28 Vidjeti tako u: Petar Klarić, Martin Vedriš, Građansko pravo, Narodne novine, Zagreb, kolovoz 2008. god. str. 583.

29 Vidjeti tako u: Hrvoje Kačer, Ante Perkušić, u: Vilim Gorenc et alt., Komentar Zakona o obveznim odnosima, RRIF, Zagreb, listopad 2005., str. 1605.

30 Vidjeti u: Ivica Crnić, Odštetno pravo, Faber \& Zgombić Plus d.o.o., Zagreb, 2004. god., str. 4. 
251. u svezi s odredbom članka 4. ZOO-a). Na ovu odgovornost odgovarajuće se primjenjuje normativa o deliktnoj odgovornosti. Zakon sadrži posebne odredbe glede popravljanja štete iz osnova povrede ranije preuzete ugovorne obveze, tj. o ugovornoj odgovornosti (članak 342.-349.). Odredbe o izvanugovornoj (članak 1045.-1110. ZOO-a) odgovornosti za štetu, kao opće odredbe odgovornosti za štetu, primjenjuju se i na ugovornu odgovornost, ukoliko za ugovornu odgovornost nije što drugo propisano (čl. 349. ZOO-a).

Kako smo naveli, šteta je umanjenje nečije imovine (obična šteta), sprečavanje njezina povećanja (izmakla korist) i povreda prava osobnosti (neimovinska šteta). Uočljiva je bitna razlika između ove i ranije zakonske definicije na planu neimovinske (ranije nematerijalne) štete, prema kojoj je šteta bila definirana kao umanjenje nečije imovine (obična šteta), sprečavanje njezina povećanja (izmakla korist ${ }^{31}$ i nanošenje nekome psihičkog ili fizičkog straha ili bola. Razlika ni u kojem slučaju ne smije biti shvaćena kao formalna ili samo terminološka.

Da bi došlo do odgovornosti za štetu, između štetne radnje i štete mora postojati uzročna veza - kauzalni neksus. Šteta se mora javljati baš kao posljedica štetne radnje. Šteta obično nastupa kao posljedica više uzroka, pa je u okolnostima svakog slučaja potrebno cijeniti onaj uzrok koji je pravno relevantan. To je uzrok koji je tipičan (prema životnom iskustvu ili pravilima struke, uobičajenom životnom tijeku stvari) za određenu štetnu posljedicu. Tako je prema sudskoj praksi pravno relevantni uzrok štete onaj štetni događaj čijem redovitom učinku odgovara konkretna šteta. Na oštećeniku je uvijek ${ }^{32}$ teret dokaza glede uzročne veze, zato jer se ista ne predmnijeva.

O protupravnosti govorimo kada je povrijeđena neka pravna norma. Pri tom nije riječ samo o normama građanskog prava jer i ponašanje suprotno normama drugih pravnih područja može dovesti do štete. Prema načelnoj odredbi članka 8. ZOO-a, svatko je dužan uzdržati se od postupka kojim se može drugom prouzročiti šteta (neminem leadere), dok je odredbom članka 1045. ZOO-a normirana obveza štetnika da naknadi štetu koju je prouzročio. Utoliko, da bi došlo do odgovornosti za štetu, nije potrebno da pravo, koje je u pojedinom slučaju povrijeđeno, izričito predviđa odgovornost za štetu. Isto tako, u okolnostima protupravnog ponašanja s kojim u uzročno-posljedičnoj vezi nije nastupila šteta neće biti ispunjene pretpostavke odgovornosti za štetu. U ovom slučaju osoba koja je povrijedila pravnu normu može odgovarati npr. kazneno i/ili za prekršaj, ali kako u pravno relevantnoj uzročnoposljedičnoj vezi s njegovim postupanjem nije nastupila šteta (njegovim postupanjem nije povrijeđeno subjektivno pravo ili pravom zaštićeni interes druge osobe), neće biti ostvarene pretpostavke odgovornosti za štetu. Postoji li u pojedinom slučaju protupravnost kao pretpostavka odgovornosti za štetu, ocjenjuje se ovisno o tome

31 Glede prva dva dijela definicije, nije došlo do promjene.

32 Naš je zakonodavac odredbom čl. 1063. ZOO-a odstupio od ovog rješenja kod odgovornosti od opasne stvari i opasne djelatnosti na način da je propisana (oboriva) predmnjeva uzročnosti. Vidjeti više o uzročnosti u: Petar Klarić, „Uzročna veza kod odgovornosti za štete u medicini“, u: Aktualnosti zdravstvenog zakonodavstva i pravne prakse, Zbornik radova sa savjetovanja održanog u Novalji 6 . i 7 . svibnja 2011. god., str. 137-148. 
traže li se za protupravnost samo objektivni ili i subjektivni elementi protupravnosti. Kad se kod protupravnosti traže samo objektivni elementi, od odlučnog je značaja činjenica da je štetnik svojim postupanjem povrijedio normu objektivnog prava, dok je odnos počinitelja prema radnji i nanesenoj šteti (krivnja) irelevantan. Subjektivni elementi protupravnosti izražavaju se krivnjom počinitelja. U ovom slučaju nije dovoljna činjenica da je štetnik svojim postupanjem povrijedio normu objektivnog prava, već se zahtijeva i određeni stupanj štetnikove krivnje.

Posebno su predviđeni izuzeci kada se i unatoč postojanju protupravnosti odgovornost za štetu modificira ili se protupravnost čak i isključuje. To su u ZOO-u sljedeći slučajevi: nužna obrana (čl. 1052., st. 1.), stanje nužde (čl. 1052., st. 2.), dopuštena samopomoć (čl. 1053.) i pristanak oštećenika (čl. 1054.).

\section{SPORTAŠ I TRENER ${ }^{33}$}

Sportaš je, sigurni smo, apsolutno najvažnija kategorija u sportu uopće, sportaš je ona kategorija bez koje sporta niti ima niti ga može biti, dakle to je condicio sine qua non sporta. Zakon o sportu izravno sportašima posvećuje (samo) tri članka (6. - 8.), ali to je podatak koji ne bi smio zavarati. Naime, pitanja sportaša praktično su sadržana u svim zakonskim člancima cijelog Zakona, manje ili više izravno ili neizravno. ${ }^{34}$ Naravno, ključne su odredbe baš ove u čl. 6. - 8. i na njih treba obratiti posebnu pozornost. Ono što treba jasno naglasiti (ali i pohvaliti) ${ }^{35}$ jest to da Zakon sadrži zakonsku definiciju pojma sportaš ${ }^{36}$ kao osobe koja se priprema i sudjeluje u sportskim natjecanjima. Zakonska definicija je jasna, na jednoj strani su oni koji se (pojednostavljeno) pripremaju za natjecanje i natječu (ili u okviru pravne osobe koja obavlja sportsku djelatnost sudjelovanja u sportskim natjecanjima ili kao osoba koja obavlja samostalnu sportsku djelatnost sudjelovanja u sportskim natjecanjima) i to su sportaši, i na one koji se ne natječu i koji nisu sportaši.

33 Ovaj dio u bitnom je preuzet iz: Hrvoje Kačer, Blanka Kačer, „Osobe (ili subjekti) u sustavu sporta u hrvatskom pravu“, u: Hrvoje Kačer et alt., Sportsko pravo, Pravni fakultet Sveučilišta u Splitu, Split, 2018., str. 40-62. Naravno, uporaba jednog spola ne ograničava sadržaj na jedan, nego se ravnopravno odnosi i na muški i na ženski spol.

34 A na sportaše se, naravno, primjenjuju i druge pravne norme iz drugih propisa (npr. pravna $i$ poslovna sposobnost iz ZOO-a). sportaša.

35 Razlog je pohvale što npr. nema definicije sporta, pa je očito bilo moguće da nema ni definicije

36 Što, na žalost, ne vrijedi za pojam šport. Treba naglasiti da postoji razlika u odnosu na tzv. prvo čitanje jer se očito odustalo od predložene zakonske definicije sporta koja je temeljena na dvodiobi na natjecateljski sport i sportsku rekreaciju kao osnovnu podjelu - Zakon zakonsku definiciju uopće ne poznaje.

Odustalo se, dakle (iz razloga koje je teško prepoznati) od definicija sporta kao tjelesne aktivnosti

organizirane radi postizanja sportskih dostignuća prema utvrđenim natjecateljskim pravilima (natjecateljski šport) $\mathrm{i}$

radi zaštite i unapređenja zdravlja, zabave i razonode (sportska rekreacija),

što je bio sadržaj u prvom čitanju, i to baš u osnovnom, prvom članku. 
Iako po značenju nije i ne može biti ispred sportaša, trener ${ }^{37}$ je odmah drugi po značenju koje ima, dakle odmah iza sportaša. Međusobni odnos trenera i sportaša je, u pravilu, jako zatvoreni i na neki način začarani krug, krug prepun otvorenih pitanja. Ako nema sportaša, po naravi stvari nema ni trenera jer oni nemaju koga trenirati, ${ }^{38}$ ali u pravilu bez trenera nema ni sportaša, barem ne onih s najvišim dosezima. ${ }^{39}$ Zakon o sportu trenerima je posvetio u osnovnom dijelu samo jedan članak sa šest stavaka (čl. 9.), te u prijelaznim i završnim odredbama još poseban čl. 90. koji ima (samo) dva stavka. Neovisno o onome što se velik dio odredbi Zakona o sportu (barem neizravno) odnosi i na trenere, ipak je broj od jednog, odnosno dva izravna članka (koji čak nisu ni povezani u logičnu i preglednu cjelinu sukladno pravilima nomotehnike) pokazatelj zasigurno nedostatne pozornosti prema značenju i ulozi trenera $\mathrm{i}$ to sigurno dodatno uzrokuje i značajne probleme u praksi. Moramo primijetiti da se opseg rješenja u Zakonu na žalost (barem dijelom) odrazio i na kakvoću samih zakonskih rješenja.

Treba naglasiti da je u hrvatskom sportu problem trenera kroničan, i to iz niza različitih, vrlo složenih i međusobno prožetih razloga. Ključno je u prvom redu to da nema sustava, ${ }^{40}$ da su veliki problem financije ${ }^{41}$ i da su treneri (pre)često bez odgovarajućih kvalifikacija. ${ }^{42}$ Iako će se svi rado složiti da je apsolutno najvažniji trenerski rad na početku sportaševa bavljenja sportom (npr. u teniskoj ili nogometnoj školi) notorno je da su ti poslovi najslabije i cijenjeni i plaćeni i na njima radi, na žalost, takav kadar. To znači da ti treneri iskoriste prvu prigodu koja im se pruži i promijene radno mjesto. Poseban je problem i to što treneri nisu ni na koji način izjednačeni sa sportašima u pogledu posebnih trajnih novčanih naknada za one koji su osvojili medalje na olimpijskim i svjetskim prvenstvima ${ }^{43}$ - trenera tu nema iako je vrlo često njihov utjecaj na rezultat izniman, ${ }^{44}$ a dosta je znakovito i što je nedavno objavljeno da je baš Ante Kostelić izgubio status kao trener kod Hrvatskog

37 Vidjeti i: Hrvoje Kačer, Andrea Čeh, „Treneri u novom zakonu o športu“, Novi informator, broj 5517. od 20. I. 2007., str. 17-18.

38 Druga je stvar rekreacija.

39 Neki sportaši za sebe tvrde da su samouki, neki nemaju službenog trenera ili ga imaju samo ad hoc (takav primjer je do prije godinu ili dvije bio Roger Federer prije nego što je njegov trener posatao Ivan Ljubičić), ali to je ipak samo formalni aspekt. Praktično je svakoga netko barem nešto poučio, pa onda to znači da je svatko barem imao trenera, čak i ako je to trajalo kratko i ako ga nema više.

40 Iznimke samo potvrđuju pravilo.

41 Misli se na financije generalno, što ne znači da neki treneri ne ostvaruju izvanredne prihode, $i$ to ne samo u nogometu, kako se obično misli.

42 Bili bi komični, da nisu tragični slučajevi koji su česti u nogometu da trener (u pravilu dosta poznat, dosta skup i s dobrim medijskim praćenjem) sjedi na klupi u ulozi koja nije trenerska, za koju se ne zahtijeva kvalifikacija, a pored njega sjedi njegov pomoćnik ili pomoćnikov pomoćnik koji ima kvalifikaciju. Sve ovo se radi javno i još i objašnjava u medijima, a nikakve (barem ne javne i učinkovite) reakcije mjerodavnih nema.

43 Novela Zakona o sportu iz 2013. god.

44 Uzmimo za primjer samo Antu Kostelića koji je nakon „stvaranja“ svoje djece Ivice i Janice sada (u poznim godinama) na najboljem putu da „stvori“ nove skijaške zvijezde u likovima braće Elijasa $\mathrm{i}$ Samuela Kolege koji su već osvojili bodove u Svjetskom kupu. 
olimpijskog odbora ${ }^{45}$ Zakonska definicija sadržana u čl. 9. st. 1. Zakona o sportu određuje da je trener osoba koja programira i provodi sportsku pripremu, sportsku rekreaciju i sportsku poduku.

Prema Zakonu (čl. 9. st. 2), trener mora imati stručnu spremu najmanje na razini trenera prvostupnika sukladno posebnom propisu. Ovu odredbu, koja na prvi pogled djeluje strogo, ipak treba sagledavati u kontekstu sljedeća dva stavka koji je u bitnom relativiziraju, jednako kao i čl. 90. Zakona, što daje potpuno drugu sliku čak i bez uvida u praksu koja je više nego tolerantna prema trenerima. Budući da je ta tolerancija daleko izvan zakonskih okvira, pitanje je samo do kada će trajati, ali i na čemu se temelji, uz veliki i realan strah da je to, unatoč sigurno plemenitim pobudama, školski primjer pravne nesigurnosti i vladavine neprava, drugim riječima, to je put do pakla popločan dobrim namjerama. Međutim, neovisno o tome, treba primijetiti da posebnog propisa o prvostupniku još uvijek nema, pa se može (po našem mišljenju apsolutno pogrešno) zaključiti i da trener može biti prvostupnik prava, ekonomije i sl. Svakako nema opravdanja za izostanak ovog preciziranja, ali dodatno treba prigovoriti i to što je prvostupnik kineziolog po Zakonu kvalificiran biti trener u svim sportovima, a notorno je da postoji velik broj sportova o kojima kineziolog za vrijeme studija u pravilu nije čak ni čuo, da o bilo kakvoj praksi i ne govorimo (npr. bob i skijaški skokovi u zimskim sportovima). To znači da je Zakon (svjesno) legalizirao trenersku djelatnost za osobu koja je kvalificirana samo glede tzv. općih pitanja (npr. zagrijavanje, istezanje i sl.), a po pitanjima struke u užem smislu izgledan je nastanak veće štete nego koristi.

Zakon dopušta (čl. 9. st. 3.) da poslove trenera obavlja i osoba koja nema (najmanje) stručnu spremu prvostupnika, ali ima barem jedan od posebnih alternativnih uvjeta:

a) osposobljenost putem ustanove za osposobljavanje kadra na temelju programa za stjecanje licencije krovnih svjetskih ili europskih udruženja određenog sporta ILI

b) koja je osvojila medalju na olimpijskim igrama, svjetskim ili europskim seniorskim prvenstvima i stručno je osposobljena putem ustanove za osposobljavanje kadra u športu ILI

c) koja je poslove trenera obavljala najmanje 15 godina do dana stupanja na snagu Zakona i stručno je osposobljena putem ustanove za osposobljavanje kadra u sportu.

Rješenja koja sadrži čl. 90. Zakona gotovo je nemoguće razumjeti, odnosno prihvatiti, a i čl. 9. je nužno sagledati u svezi sa čl. 90. Zakona, odnosno bez tog i takvog sagledanja nije moguće dobiti pravu sliku normative, odnosno pravnog okvira. Radi se (u članku 90.) o dijelu prijelaznih i završnih odredbi, dakle odredbi koje imaju za cilj omogućiti funkcioniranje u prijelaznom razdoblju i sastavni su

45 Vidjeti: Ivica Žurić, „Sramota hrvatskog sporta“; Kostelić nakon 10 olimpijskih medalja više nije vrhunski trener!, www.tportal od 26. III. 2018., uvid 24. I. 2019., 8:50h. 
dio velikog broja propisa ${ }^{46}$ Radi se o članku koji sadrži dva stavka. U prvom je propisano da osobe koje ne ispunjavaju uvjete što ih Zakon propisuje za trenere, a na dan stupanja na snagu Zakona rade kao treneri, imaju obvezu u roku od osam godina $^{47}$ steći odgovarajuću stručnu spremu. Premda to nije izrijekom propisano, odredba ima smisla samo ako se tumači na način da oni u međuvremenu mogu nastaviti raditi.

Sljedeći stavak odnosi se na one:

a) koji su obavljali poslove trenera najmanje 15 godina do dana stupanja na snagu Zakona ${ }^{48}$ ili

b) koji su osvojili medalju na olimpijskim igrama, svjetskim ili europskim seniorskim prvenstvima, ${ }^{49}$ a nisu stručno osposobljeni putem ustanove za obrazovanje kadra u sportu - oni mogu nastaviti ${ }^{50}$ obavljati svoje poslove kao treneri, ali imaju obvezu stručno se osposobiti u roku od tri godine. Ovo je kategorija koja bi po naravi stvari morala biti povlaštena u odnosu na one iz prvog stavka, a to na žalost (ipak) nije tako, ili barem to ne proizlazi iz sadašnjih formulacija Zakona.

Ono što je moguće ocijeniti samo kao katastrofu u svakom pogledu je to što nikada nitko nije (a mogao je i morao je) napravio popis trenera na koje se odnosi odgoda od 8 (11) godina, što nikad nitko nije (a mogao je i morao je) provjerio koliko je osoba upisalo studij za stjecanje odgovarajuće stručne spreme prvostupnika i kako na tom studiju napreduju. ${ }^{51}$ Pri tome zakonodavac nije „dirao“" u stavak drugi pa bi trebalo zaključiti ili:

a) da je isti ab initio bio nepotreban ili

b) da su se svi osposobili (što potpuno sigurno nije točno). Iako je samo produžavanje roka svima (što znači i onima koji do tada nisu ni upisali studij, pa posljedično nisu ni imali mogućnost u roku od dodatne tri godine isti dovršiti) samo po sebi loše, još lošije je što su i zakonodavac i izvršna vlast dopustili da i produženi rok prođe, a da se ne napravi baš ništa - niti je (ponovno) produžen rok, niti je kontrolirano tko je i do koje razine dospio u obrazovanju, da o nekom sustavnom pristupu (npr. pomoć kod financiranja) i ne govorimo. SAPIENTI SAT!

46 Ili svakog propisa ako mislimo i na odredbe o stupanju na snagu.

47 Novelom je rok produžen na 11 godina.

48 Ali nije nužno da su radile kao treneri na dan stupanja na snagu Zakona.

49 Vjerujemo da se ovo odnosi i na one koji medalje osvoje i nakon stupanja na snagu Zakona. Šteta je ipak što nema ograničenja na sport u kojemu je medalja osvojena. Svakako bi se moralo odnositi i na paraolimpijce.

50 Pojam „nastaviti“ prilično sigurno upućuje na to da se mislilo na one koji rade kao treneri, a ne na one koji su to radili npr. prije desetak godina. Ako nije tako, odredba je besmislena.

51 Na žalost, kada su vidjeli kako se izvršna vlast prema njima odnosi, mnogi su se zadovoljili s ishođenjem indeksa kao dokaza da su studij upisali. 
Generalno nam izgleda da je dio Zakona koji se odnosi na trenere možda u cijelom Zakonu i najviše podložan kritici i da najviše zahtijeva intervencije prvom prigodom koja se ukaže - do tada je velika odgovornost na praksi, daleko manje onoj sudskoj ili upravnosudskoj zbog naravi stvari koja zahtijeva protek dosta vremena do prigode da sudovi uopće o nečemu odlučuju, a daleko više onoj upravnih tijela, u prvom redu mjerodavnog državnog ureda za sport. Iako se radi o čitavoj lepezi pitanja koja su de lege lata ili neuređena ili loše pravno uređena, ipak nam nekako najveći problem izgleda ono što u praksi još uvijek nije više od vrha ledene sante koji viri iznad površine mora.

Mislimo na građanskopravnu odštetnu odgovornost trenera prema sportašu (neovisno o tome je li između njih klub čiji je trener zaposlenik) zbog toga što nije udovoljeno vrlo jasnoj odredbi iz Zakona o obveznim odnosima o pažnji dobrog stručnjaka, o odredbi članka 10. koja glasi:

1) Sudionik u obveznom odnosu dužan je u ispunjavanju svoje obveze postupati s pažnjom koja se u pravnom prometu zahtijeva u odgovarajućoj vrsti obveznih odnosa (pažnja dobrog gospodarstvenika, odnosno pažnja dobrog domaćina).

(2) Sudionik u obveznom odnosu dužan je u ispunjavanju obveze iz svoje profesionalne djelatnosti postupati s povećanom pažnjom, prema pravilima struke i običajima (pažnja dobrog stručnjaka).

(3) Sudionik u obveznom odnosu dužan je u ostvarivanju svog prava suzdržati se od postupka kojim bi se otežalo ispunjenje obveze drugog sudionika.

Jasno postavljamo pitanje koje smatramo neopisivo važnim za sport, sportaše i trenere - koliko trenera bilo koje (trenerske) razine u Republici Hrvatskoj (ili bilo kojoj drugoj državi) ima barem osnovne podatke (koje ažurira) o tome što je šteta, što je odštetna odgovornost, što je pažnja dobrog stručnjaka, što je sudska praksa, što je tumačenje u pravu, što je regres, što je solidarnost, što je...? Čak i bez nekog posebnog istraživanja, odgovorno tvrdimo da se od odgovora svi zajedno moramo jako prestrašiti i da sve zajedno to podsjeća na izreku CAR JE GOL. Naime, količina znanja o navedenome zaprepašćujuće je niska, a ne vidimo trend koji bi to mijenjao. Pri tome je jasno da su i zakonodavac (lošim zakonskim rješenjima) i izvršna vlast (pasivnošću, dakle neprovođenjem inspekcijskog i drugog nadzora) dali mnogo doprinosa aktualnom lošem stanju i normative i prakse.

\section{V.1. TRENERI I PAŽNJA DOBROG STRUČNJAKA}

U skladu s najavljenim na početku ovog rada (niz radova u svezi s odštetnom odgovornosti), smatrali smo korisnim na ovom mjestu, bez ikakvih nakana $\mathrm{k}$ taksativnom nabrajanju, primjerično navesti ono o čemu svaki trener (kako bi izbjegao ili barem minorizirao građanskopravnu odgovornost) MORA i te kako voditi računa.

Svaki trener mora, uz marljivost u obavljanju svojeg posla, biti u stanju braniti stav da je (ali u svakom trenutku) uložio pažnju dobrog stručnjaka. To ne znači 
nužno da je formalno ispunio uvjete za obavljanje poslova trenera (iako je nerad države po tom pitanju poseban problem) jer Zakon o obveznim odnosima zahtijeva kauzalni neksus između rada ili nerada trenera i štete koja je nastupila, a to sigurno nije u svezi (izravnoj) s time ima li on ili nema diplomu.

Na primjeru bilo kojeg sportaša, prva krizna točka u pravilu će biti odabir sporta koji je za konkretnu osobu najprikladniji. Radi se o procesu koji je sofisticiran i vrlo realan i taj proces bi trebalo proći baš svako dijete prije odluke kojim će se sportom baviti. Naravno, moguće je (čak i lako moguće, osim ako dijete živi u Zagrebu) da u mjestu stanovanja djeteta nekog sporta uopće nema ili je pak slabo razvijen ${ }^{52}$ tako da se možda najprikladnijim sportovima dijete uopće ne može baviti. Nužno je u svakom konkretnom slučaju, uzimajući u obzir sve okolnosti (svakako i sklonost djeteta), donijeti najbolju odluku u interesu djeteta. Taj postupak u posljednje se vrijeme organizirano provodi u Splitu i u Zagrebu od strane grada, odnosno gradskih ustanova koje se bave sportom, i na raspolaganju imaju niz stručnjaka različitih profila koji jamče kvalitetan i multidisciplinaran pristup. To je sigurno bolje od bilo kakve individualne prosudbe.

Nakon odabira konkretnog sporta (ili možda sportova, neko vrijeme i ta konkurencija može biti dobro rješenje), slijedi upis u klub i početak treninga. Preduvjet je, naravno, temeljiti liječnički pregled koji rezultira dopuštenjem za bavljenje sportom ili pak negativnom odlukom jer je pronađena neka smetnja. Već i sam upis opterećen je pravnom dvojbom jesu li potrebna oba roditelja, eventualno i Centar za socijalnu skrb, tim prije ako se radi o kontaktnom ili općenito opasnom sportu (i za skijaške skokove trening počinje dok je još daleko punoljetnost).

Trening može donijeti korekciju osnovne prosudbe koji je sport najprikladniji za konkretno dijete, posebno u svezi s natjecanjem, pojačanim naporima, pojačanom prehranom i sl.

Cijelo vrijeme trener ima, pored stručne, i značajnu edukativnu ulogu, što je logično ako se uzme u obzir koliko vremena dijete provodi na treningu. To uključuje i sposobnost odgovarajuće komunikacije i pomoći i za slučaj suprotnog spola, a ako je moguće da će u kratkom vremenu trener morati voditi računa ne samo o spolu, nego r rodu. $^{53}$

Za vrijeme treninga i natjecanja ne smije se dopustiti zanemarivanje škole, jer sport i sportska karijera rijetko omogućavaju egzistenciju, a naravno, ni zdravlja, pri čemu je kod djevojčica vrlo važno strogo paziti na napore za vrijeme menstruacije.

Unutar treninga, trener je ključna osoba za korekciju tehnike što zna biti složeno, posebno ako postoje (bitno) različite opcije (npr. je li dijete ljevak ili dešnjak, čak i to zna biti dvojbeno, je li bolji jednoručni ili dvoručni backhand...).

Sve naprijed navedeno svakodnevno se događa na tisućama sportskih igrališta, ali to nije baš nikakav argument u smislu da je to nešto jednostavno. Velika većina

52 Tako npr. jedan jako kvalitetan tenisač svaki dan putuje na trening u Split iz Dicma, što je udaljenost od najmanje 4 kilometara, uz prilično i skupu i lošu autobusnu vezu.

53 Mislimo na rasprave u svezi s Istanbulskom konvencijom. 
trenera jako cijeni sebe kao stručnu osobu, ali samo ako su u pravu imaju izgleda proći test - provjeru udovoljavaju li standardu ,pažnje dobrog stručnjaka“iz Zakona o obveznim odnosima. Prigodom izrade udžbenika Sportsko pravo napravljena je prigodna anketa na temu informiranosti trenera i čelnika klubova o temi dopinga i rezultati su bili apsolutno porazni. ${ }^{54}$

Pitanje je li trener udovoljio u svakoj od naprijed navedenih faza standardu pažnje dobrog (mi bismo dodali i dobronamjernog) stručnjaka, po našem mišljenju, u praksi će prečesto dobiti negativan odgovor, osim ako se jako brzo ne naprave bitni pomaci na bolje, pomaci in favorem pravnog i stvarnog položaja trenera.

\section{ZAKLJUČAK}

U uvodnom dijelu postavili smo dvije hipoteze koje smo kroz tekst trebali provjeriti. Prva treneru (generalno, neovisno o stanju kod svakog pojedinog trenera) u obavljanju trenerskog posla postavlja gotovo nevjerojatne zahtjeve koji prepoznaju trenera isključivo kao nadčovjeka, a tim zahtjevima ne mogu odgovoriti ni oni rijetki i najbolji, kamo li oni ostali, uključujući i one (netko i to mora biti) najlošije. Pri tome ne mislimo samo na stručna znanja u užem smislu (npr. u tenisu kako izvesti pojedini udarac), nego i na daleko šira znanja, od onih na području tehnike i taktike, preko snage i kondicije, pa sve do znanja iz područja borbe protiv dopinga i barem minimalnih pravničkih znanja.

Potpuno smo sigurni (samo iznimno je to moguće bez posebnog znanstvenog istraživanja) da stvarno vrlo mali broj trenera udovoljava pravnom standardu „pažnja dobrog stručnjaka“ iz Zakona o obveznim odnosima i to čak i kada se radi o stručnjacima s najvišim akademskim i stručnim titulama i dosezima. Naime, danas je notorno da je potreban multidisciplinaran pristup sportašima na treningu, a od trenera (koji je na svakom treningu nazočan) očekuje se i da vlada mnogim znanjima, pa tako npr. i osnovnim medicinskim znanjima i vještinama, uključujući davanje umjetnog disanja i sl. Uz obilje dostupne literature, ne samo u knjižnicama, kioscima i u knjižarama, nego i na internetu, lako je zamisliti kako bi sudac gledao na trenera koji prizna da je posljednju knjigu o sportu pročitao prije desetak godina, da ne posjećuje (a možda je ni ne zna), ili to radi samo povremeno, ni internetsku stranicu vlastitog saveza, ni Hrvatskog olimpijskog odbora, ni nacionalne antidoping agencije, ni... Sigurni smo da bi se sve „svalilo“ na trenera, a to u krajnjoj liniji nije ni normalno, ni opravdano. Kada zanemarimo ovu najproblematičniju kategoriju, dolazi na red ona koja raspolaže nekim potrebnim podacima i znanjima i značajnim znanjima koja se odnose na proces treninga određenog sporta u užem smislu, ali ih ne ažurira kako bi trebalo. Lako je zamisliti neko ispitivanje na sudu na kojemu bi suca npr. interesiralo zna li trener za zbornike radova sa znanstveno-stručnih (međunarodnih) savjetovanja Contemporary Kinesiology, što je npr. pročitao i

${ }_{54}$ Vidjeti više u: Hrvoje Kačer, Blanka Kačer, (neke) pravne dvojbe u svezi dopinga, u: Hrvoje Kačer et alt., SPORTSKO PRAVO, Pravni fakultet Sveučilišta u Splitu, Split, 2018., str. 544. 
zapamtio o organizacijskim i metodičkim formama rada u sportu ${ }^{55}$ ili o zakonitosti rasta i razvitka te morfološkim i funkcionalno-fiziološkim promjenama koje se zbivaju u dječjoj fazi života. ${ }^{56}$ Stvari su još dramatično lošije kada se prijeđe na pitanje npr. dopinga ili čak i na nove dvojbe kao što je pitanje spola ili roda, o čemu je izgleda lakše dobiti nekoga na prosvjed, nego na savjetovanje i raspravu.

Druga hipoteza odnosi se na to da treneri u pravilu nisu svjesni gdje su granice njihove odgovornosti i o kojim se to sve vrstama odgovornosti (građanskopravna, kaznenopravna, prekršajnopravna, stegovna) uopće radi. I glede ove hipoteze potvrdilo se da je razina znanja trenera iznimno niska.

Sigurni smo u to da je jedino rješenje koje bi popravilo položaj i status trenera u bitnom poboljšanju sustava da Hrvatski olimpijski odbor i/ili nacionalni sportski savezi i/ili Središnji državni ured za sport kontinuirano održavaju razne seminare, da isti subjekti institucionalno osiguraju svakom djetetu u cijeloj državi besplatne zdravstvene preglede specijalista sportske medicine (kojima u zamjeni moraju biti pedijatri, a ne specijalisti medicine rada), da izrade visokokvalificirane programe rada koje je razmjerno lako pravilno korigirati. Glede pravnih znanja, bilo bi definitivno najbolje edukaciju prepustiti Hrvatskom društvu za sportsko pravo koje je već niz puta kroz istupe svojih članova pokazalo i dokazalo kompetenciju na ovom području. Iznimno je važno shvatiti i prihvatiti da je proces edukacije cjeloživotni i da su davno prošla vremena u kojima se moglo doći do diplome i prestati s učenjem. Ukoliko kvalitetne naobrazbe ne bude, vrlo brzo će se sličica u kojoj trener podučava dijete, a okružuju ga (i čine rad nemogućim) policajac, državni odvjetnik, privatni odvjetnik, vještak, možda i još poneka osoba - od daleke budućnosti pretvoriti u zabrinjavajući prikaz stvarnosti. S nevjericom se svojedobno gledalo na takva predviđanja u odnosu na liječnike, a pokazalo se da je vrlo skora stvarnost bila (i ostala) daleko lošija od predviđanja. Bilo bi dobro iskoristiti tuđa iskustva i za trenere umanjiti buduće probleme (jer izbjeći ih potpuno nije moguće).

55 Vidjeti npr. Dragan Milanović, Sanja Šalaj, Igor Jukić, „Organizacijske i metodičke forme rada u sportu“ (Organisational and methodical forms of work in sport) u: Metodički organizacijski oblici rada u područjima edukacije, sporta, sportske rekreacije i kineziterapije / Neljak, Boris (ur.): Hrvatski kineziološki savez, Zagreb, 2009., str. 44-54.

56 Ilona Mihajlović: „Funkcionalne promene u trenažnom procesu vrhunskih sportista“, Sport Science 1(2008), 1:45-49. 


\section{CRISIS POINTS FOR THE ONSET OF DAMAGE IN THE SPAN OF AN ATHLETE, IN PARTICULAR FROM THE ASPECT OF THE ROLE OF THE COACH WHO DOES (NOT) WORK LEGE ARTIS}

The legal framework of the coach's possible damages liability towards the athlete is analysed in this article. Two hypotheses are starting points. The first one is possible responsibility of the athlete due to expert omissions of the coach in the training process. The second is that coaches are not aware of the limits of their liability. It is completely certain that both hypotheses place coaches in grave danger. Namely, it is correct that there is a great number of working coaches who have not satisfied legal regulations and it is even more certain that there are coaches who do not possess minimal legal knowledge. The authors are sure (although it is only exceptionally possible to make such an assumption without specific scientific research) that a very small number of coaches satisfy the legal standard of , duty of care of a good expert "from the Contracts Act, even where experts with the highest academic and practical tiles and achievements are concerned. This means that the situation with many coaches is really of the utmost concern. In so far as there is no quality education, the picture of a coach training a child surrounded by (and impede work) the police, district attorney, experts, and perhaps a few more people very quickly will soon turn into worrying picture of reality. Unbelievably, will such predictions be looked upon by physicians. It has been shown that the reality very soon was and is, in our opinion, much worse.

Key words: damage, athlete, coach, liability, solidarity liability, duty of care of a good expert 